International Journal of Computer and Information System (IJCIS)

Peer Reviewed - International Journal

Vol : Vol. 02, Issue 04, November 2021

e-ISSN : 2745-9659

https://ijcis.net/index.php/ijcis/index

\title{
Expert System for Early Diagnosis of Tropical Malaria and Tertiana Malaria using Certainty Factor
}

\author{
$1^{\text {st }}$ Patmawati Hasan, $2^{\text {nd }}$ Elvis Pawan \\ 1,2 Program Studi Teknik Informatika \\ ${ }^{1,2}$ STIMIK Sepuluh Nopember Jayapura \\ 1,2 J1. Ardipura II No.22B Polimak Jayapura Selatan Jayapura - Papua \\ 1st patmawatihasan@gmail.com, 2nd elvispawan09@gmail.com
}

\begin{abstract}
Twano Health Center is one of the technical implementing units of the Jayapura City Health Office which organizes Health Efforts, but the constraints regarding the facilities and infrastructure of the Puskesmas are not yet adequate in supporting health services. Based on observations, the increase in the level of malaria sufferers in the Jayapura area is caused by parasites (protozoa) of the genus Plasmodium and the mode of transmission is through the bite of a female Anopheles mosquito. There are two types of malaria that are often experienced by Jayapura residents, namely Tropical Malaria (Plasmodium falciparum) and Tertiana (Plasmodium vivax). The purpose of this study is to create an expert system that can diagnose early diseases such as an expert or doctor using the Certainty Factor method which expresses belief in an event (fact or hypothesis) based on evidence or expert judgment in early diagnosis of Tropical Malaria and Tertiana. The research subjects taken were 5 patients who had symptoms of Malaria and 1 doctor to determine the symptoms of the disease) The expert system using the Certainty Factor method was used because this method was suitable in determining the disease, and the result was a percentage which was the level of accuracy in determining the patient's disease. Determination of the percentage is influenced by the MB value (a measure of the increase in confidence) and the MD value (a measure of the increase in distrust) obtained from the assessment of an expert. For data modeling using data flow diagrams (DFD) and websitebased. Total accurate patient recapitulation results are $80 \%$ of the Expert System for Early Diagnosis of Tropical Malaria and Tertiana using Certainty Factor.
\end{abstract}

Keywords: Expert system, Certainty_Factor, Malaria, Tropical, Tertiana.

\section{INTRODUCTION}

All over the world, malaria cases have become a dangerous disease, especially in tropical and subtropical countries. One of the countries at risk for malaria cases in Indonesia with a prevalence of $1.4 \%$ and an incidence rate of $0.3 \%$ with the 2015 Annual Parasite Incidence (API) rate of $0.85 \%$. The World Health Organization (WHO) estimates that 300 to 500 million people are infected with malaria each year. Based on these data, there are approximately 3 million cases classified as severe malaria (complications) and deaths, especially children and pregnant women due to malaria [1].

Malaria is an acute or chronic infectious disease caused by Plasmodium infection that attacks erythrocytes and is characterized by the discovery of asexual forms in the blood, with symptoms of fever, chills, anemia, and enlarged spleen. [2]. Two types of malaria are often experienced by Jayapura residents, namely tropical malaria and tertiana which will multiply in the liver and then infect red blood cells. So far, the symptoms of malaria have only been diagnosed by the general public based on known characteristics without facts and other medical measures. So that people or sufferers find it difficult to distinguish between malaria and common fever diseases. Tropical malaria is caused by a malaria parasite called falciparum, this type of malaria is the heaviest and the only parasite that causes microvascular disease, because it can cause various serious complications such as cerebral malaria (brain malaria), severe anemia, shock, acute kidney failure, bleeding, shortness of breath, etc [2]. While Tertiana malaria is caused by a malaria parasite called vivax, where the symptoms of this disease are almost the same as high fever but it will be easy to recover but it takes 2-3 months because this type of disease will often recur if the body condition is not healthy [2].
Twano Health Center is the 13th Public Health Center of the City Health Office. The Puskesmas is the most basic health service and is the spearhead in the field of health services, so that it requires every Puskesmas to have specificity in every effort to provide health services. [3]. Based on observations, the increase in the level of malaria sufferers in the Jayapura area is caused by parasites (protozoa) of the genus Plasmodium and the mode of transmission is through the bite of a female Anopheles mosquito. Plasmodium parasites will multiply in the liver and then infect red blood cells which eventually causes patients to experience symptoms of malaria such as symptoms in patients with influenza, if not treated, it will get worse and complications can occur which can lead to death. There are two types of malaria that are often experienced by Jayapura residents, namely Tropical Malaria (Plasmodium falciparum) and Tertiana (Plasmodium vivax)[4].

Expert systems are currently widely used by humans, such as making it easier for people without having to consult a doctor or expert, being able to find out the symptoms of the disease early. An expert system is also a computer system that can perform reasoning from an expert with expertise in a particular field [4]. And basically the expert system is applied to support problem solving activities usually used for consultation, analysis, diagnosis, and help make decisions [5]. Expert systems are designed so that expertise from experts to computers and then transferred to other people who are not experts is the main goal of expert systems [6].

One of the techniques used to overcome uncertainty in decision making is by using the Certainty Factor which expresses belief in an event based on evidence or expert judgment. Certainty Factor uses a value to assume the degree of confidence of an expert in a data [5]. 
International Journal of Computer and Information System (IJCIS)

Peer Reviewed - International Journal

Vol : Vol. 02, Issue 04, November 2021

e-ISSN : 2745-9659

https://ijcis.net/index.php/ijcis/index

In order to make it easier for Twano Health Center patients to detect malaria early and not be late in getting treatment because doctors have limited time. Then built a system that can help solve these problems in the form of an expert system with the Certainty Factor method.

As for research related to expert systems using Certainty Factor, among others, previous research by Abdi Pandu Kusuma and Agung Sugiarto who applied the Certainty Factor method to the diagnosis of first aid due to mosquito bites based on Android with the acquisition of respondent testing of $40.0 \%$ stating that the appearance of this system was good. to be applied by users [7]. Then furthermore by Yogi Permana, I Gede Pasek Suta Wijaya, and Fitri Bimantoro using the Certainty Factor (CF) method is an Android-based eye disease diagnosis with a diagnostic accuracy rate of $75 \%$ with details of 15 diseases and 52 symptoms [8].

Based on the problems and research that has been done by previous researchers, the author design and build an expert system to make it easier for Twano Health Center patients to detect malaria early and not be late in getting treatment because doctors have limited time. Then built a system that can help solve these problems in the form of an expert system with the Certainty Factor method.

\section{RESEARCH METHODS}

The Research Method describes the Research Flow, Certainty Factor, DFD context diagram, relations between tables, knowledge base.

\subsection{Research Flow}

In conducting research there are several important stages, the first stage is the Literature Study which is sourced from the results of previous research such as journals, proceedings, and books which aim to formulate the background, state of the art, and theoretical basis. The second stage is an interview sourced from an expert to provide symptoms of tropical and tertian malaria along with the MB and MD values for each symptom. The third stage of System Modeling, at this stage using data flow diagrams to be able to create context diagrams and DFD level 1. The fourth stage is System Design using the PHP programming language and implementation of the Centairty Factor method, then the fifth stage of application testing by utilizing the Blackbox method to find out system performance is functioning properly. To further clarify the steps in this study, it can be seen in Figure 1.

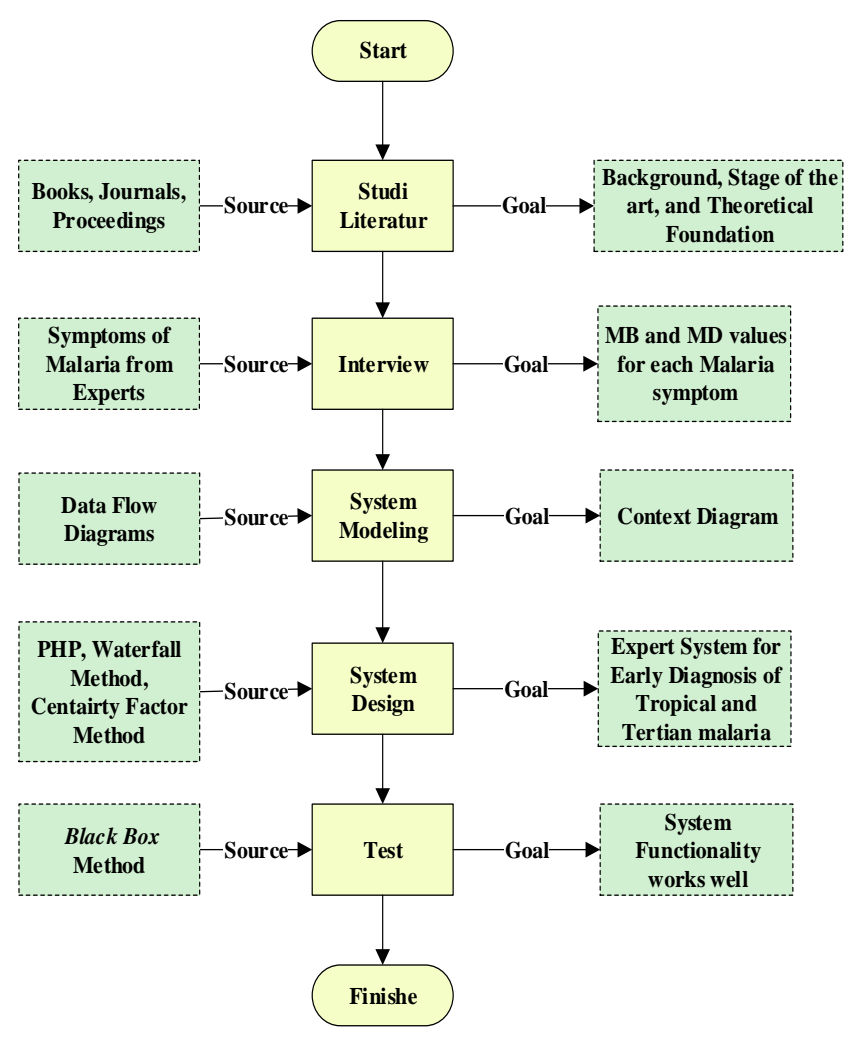

Figure 1. Research Flow

\subsection{Certainty Factor}

Certainty factor is a method to prove whether a fact is certain or uncertain in the form of a metric that is usually used in expert systems. This method is very suitable for expert systems that diagnose something that is not certain [7]. The following is the notation for the Certainty factor [5] :

$C F(h, e)=M B(h, e)-M D(h, e)$

In one case there will be more than one measure of the increase in confidence according to the many symptoms that the hypothesis has, so the MB and MD formulas are as follows:

$\begin{aligned} M B\left[h, e_{1} \Delta e_{2}\right] & =\left\{\begin{array}{lr}0 & M D\left[h, e_{1} \Delta e_{2}\right]=1 \\ M B\left[h, e_{1}\right]+M B\left[h, e_{2}\right] .\left(1-M B\left[h, e_{1}\right]\right) & \text { lainnya }\end{array}\right. \\ M D\left[h, e_{1} \Delta e_{2}\right] & =\left\{\begin{array}{lr}0 & M B\left[h, e_{1} \Delta e_{2}\right]=1 \\ M D\left[h, e_{1}\right]+M D\left[h, e_{2}\right] .\left(1-M D\left[h, e_{1}\right]\right) & \text { lainnya }\end{array}\right.\end{aligned}$

Information:

$\mathrm{CF}(\mathrm{h}, \mathrm{e}) \quad$ certainty factor of the hypothesis $\mathrm{h}$ which is influenced by the symptoms (evidence) e. The amount of CF ranges from -1 to 1 . A value of -1 indicates absolute distrust, while a value of 1 indicates absolute trust.

MB(h,e) measure of increased belief (measure of increased belief) on the hypothesis $\mathrm{h}$ which is influenced by the symptoms of $\mathrm{e}$. 
International Journal of Computer and Information System (IJCIS)

Peer Reviewed - International Journal

Vol : Vol. 02, Issue 04, November 2021

e-ISSN : 2745-9659

https://ijcis.net/index.php/ijcis/index

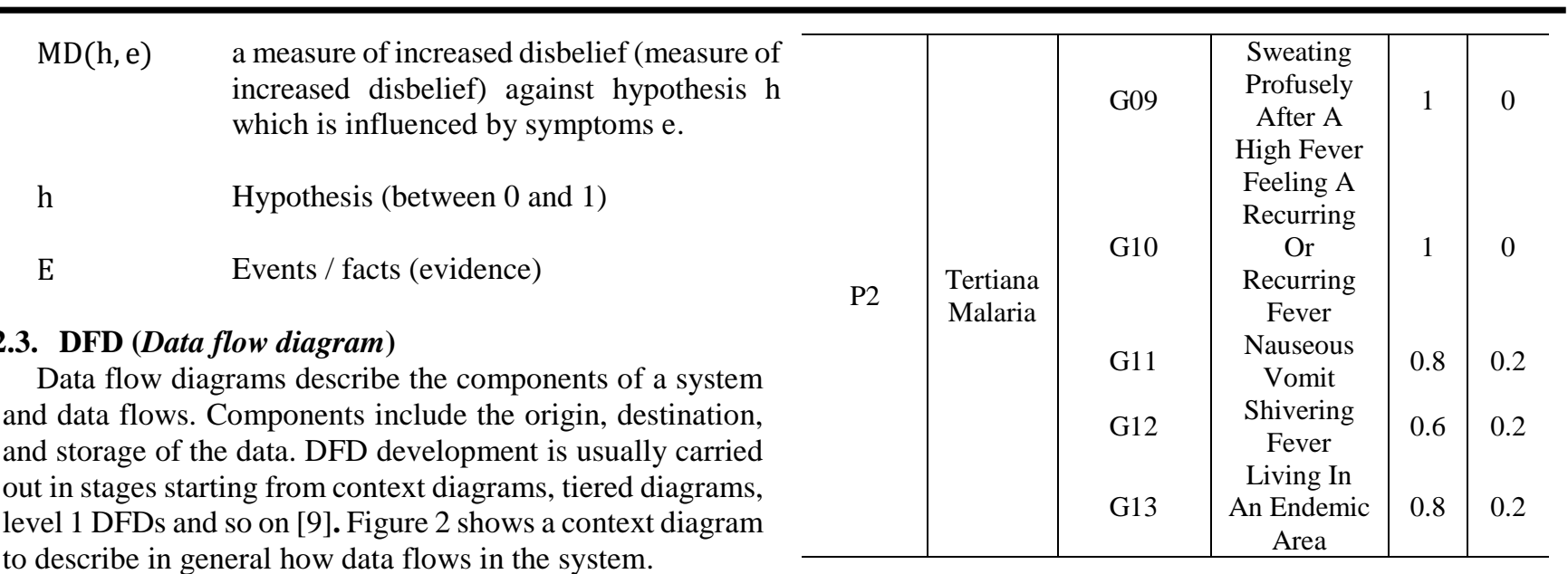

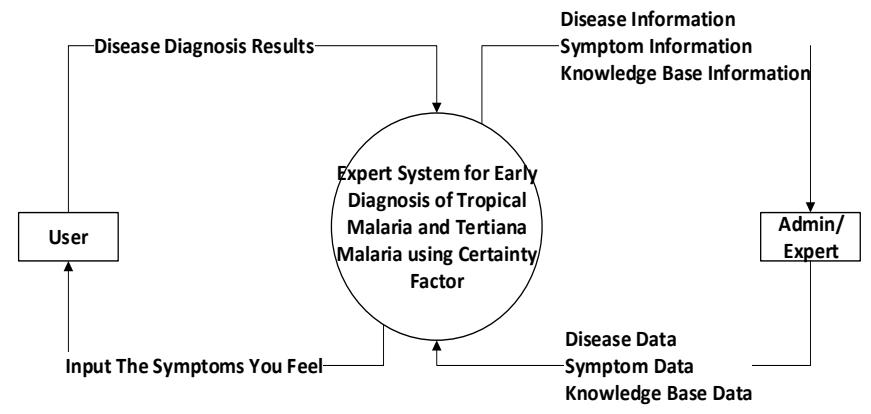

Figure 2. Context Diagram

\subsection{Knowledge Base}

One of the important components in an expert system is a knowledge base, which is a representation of knowledge from experts, and non-formal knowledge, which comes from books, articles, or journals. The knowledge base is composed of facts in the form of information about objects, events, or situations, and rules in the form of information on how to generate new facts from existing facts [8]. The following types of diseases and symptoms are the types of diseases and symptoms of each tropical and tertian malaria in Table 1.

Table1. Knowledge Base

\begin{tabular}{|c|c|c|c|c|c|}
\hline $\begin{array}{c}\text { Disease } \\
\text { Code }\end{array}$ & $\begin{array}{c}\text { Disease } \\
\text { Name }\end{array}$ & $\begin{array}{c}\text { Symptom } \\
\text { Code }\end{array}$ & $\begin{array}{c}\text { Symptom } \\
\text { Name }\end{array}$ & MB & MD \\
\hline \multirow{8}{*}{ P1 } & \multirow{8}{*}{$\begin{array}{l}\text { Tropical } \\
\text { Malaria }\end{array}$} & G01 & $\begin{array}{l}\text { Shivering } \\
\text { Fever }\end{array}$ & 0.8 & 0.2 \\
\hline & & G02 & Nosebleed & 0.8 & 0.2 \\
\hline & & G03 & Headache & 1 & 0 \\
\hline & & G04 & Body Pain & 0.8 & 0.2 \\
\hline & & G05 & Anemia & 0.6 & 0 \\
\hline & & G06 & $\begin{array}{l}\text { Living In } \\
\text { An Endemic } \\
\text { Area }\end{array}$ & 0.8 & 0.2 \\
\hline & & G07 & $\begin{array}{c}\text { Red Spots } \\
\text { On The } \\
\text { Body }\end{array}$ & 0.6 & 0.2 \\
\hline & & G08 & $\begin{array}{l}\text { Out Of } \\
\text { Breath }\end{array}$ & 1 & 0.2 \\
\hline
\end{tabular}

\section{RESULT AND ANALYSIS}

\subsection{Calculation of Tropical Malaria and Tertiana Malaria}

Based on the results of interviews with doctors who were at the Twano Health Center regarding one of the samples of patients affected by malaria to choose the early symptoms that were felt at this time to know the results of the diagnosis based on the results of the highest percentage of the two diseases using the Certainty Factor method. The following is a table symptom based on MB and MD values, which can be seen in Table 2.

Table 2. Selected Symptom Sample

\begin{tabular}{|c|c|c|c|}
\hline $\begin{array}{c}\text { Symptom } \\
\text { Code }\end{array}$ & Symptom Name & MB & MD \\
\hline G07 & $\begin{array}{l}\text { Red Spots On The } \\
\text { Body }\end{array}$ & 0.6 & 0.2 \\
\hline G09 & $\begin{array}{l}\text { Sweating Profusely } \\
\text { After A High Fever }\end{array}$ & 1 & 0 \\
\hline G10 & $\begin{array}{l}\text { Feeling A Recurring } \\
\text { Or Recurring Fever }\end{array}$ & 1 & 0 \\
\hline G11 & Nauseous Vomit & 0.8 & 0.2 \\
\hline
\end{tabular}

Calculations with the Certainty Factor method are as follows [5] in the equation $(1,2,3)$ :

\section{Disease 1 : Tropical Malaria \\ Symptom 1 : [G07] Red Spots On The Body}

$$
\begin{array}{ll}
\text { MB Old } & : 0 \\
\text { MD Old } & : 0 \\
\text { MB New } & : 0.6 \\
\text { MD New } & : 0.2 \\
\text { MB Temporary } & : 0.6 \\
\text { MD Temporary } & : 0.2 \\
\text { CF } \quad: \text { MB Temporary - MD Temporary } & \\
\quad: 0.6-0.2 & : 0.4 \\
\text { CF } \quad: 0.4 * 100 \% \\
\quad: 40 \% \text { Tropical Malaria] }
\end{array}
$$


International Journal of Computer and Information System (IJCIS)

Peer Reviewed - International Journal

Vol : Vol. 02, Issue 04, November 2021

e-ISSN : 2745-9659

https://ijcis.net/index.php/ijcis/index

2.Disease 2 : Tertiana Malaria

Symptom 2 : [G09] Sweating Profusely After A High Fever

$\begin{array}{ll}\text { MB Old } & : 0 \\ \text { MD Old } & : 0 \\ \text { MB New } & : 1 \\ \text { MD New } & : 0 \\ \text { MB Temporary } & : 1 \\ \text { MD Temporary } & : 0\end{array}$

Symptom 3 : [G10] Feeling A Recurring Or Recurring Fever

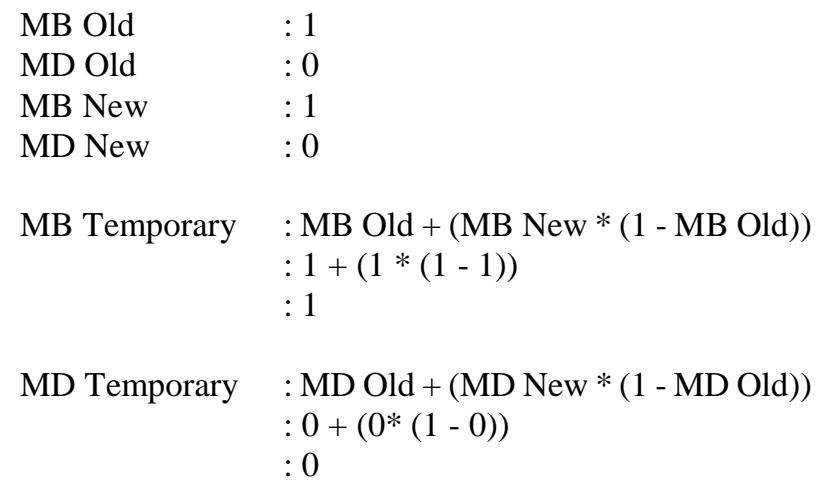

Symptom $4 \quad$ : [G11] Nauseous Vomit

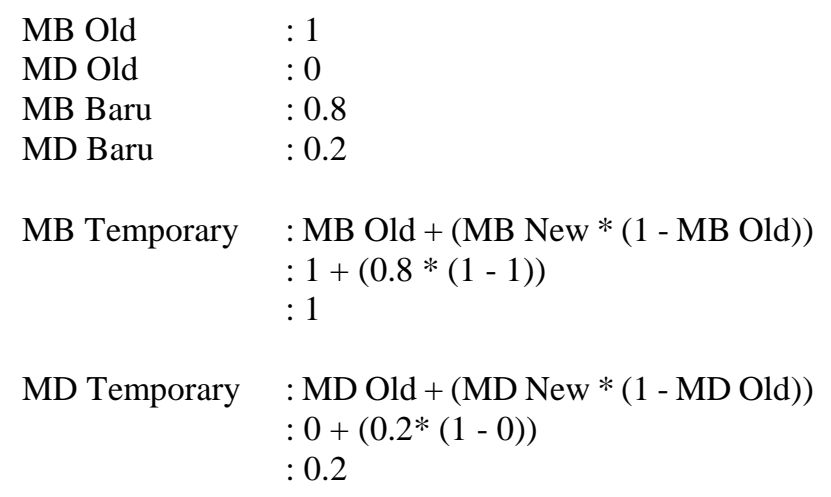

CF : MB Temporary - MD Temporary

$: 1-0.2$

$: 0.8$

$\mathrm{CF} \quad: 0.8 * 100 \%$

: $80 \%$ [Tertiana Malaria]

From the results of calculations using the Certainty Factor method in equation $(1,2,3)$ by inputting 4 symptoms, namely [G07] Red Spots On The Body, [G09] Sweating Profusely After A High Fever, [G10] Feeling A Recurring Or Recurring Fever, [G11] Nauseous Vomit who get the results of the diagnosis of Tropical Malaria symptoms by $40 \%$ and Tertiana Malaria by $80 \%$. However, only a higher percentage will be made the final decision as a result of the diagnosis. The final decision is Tertiana Malaria which has the highest percentage as a result of the diagnosis.

\subsection{Implementation}

Implementation of the Expert System for Early

Diagnosis of Tropical Malaria and Tertiana Malaria using Certainty Factor describes the appearance of the system and the test results.

This expert system displays a login form when the admin wants to enter the main page, the login form can be seen in Figure 3.

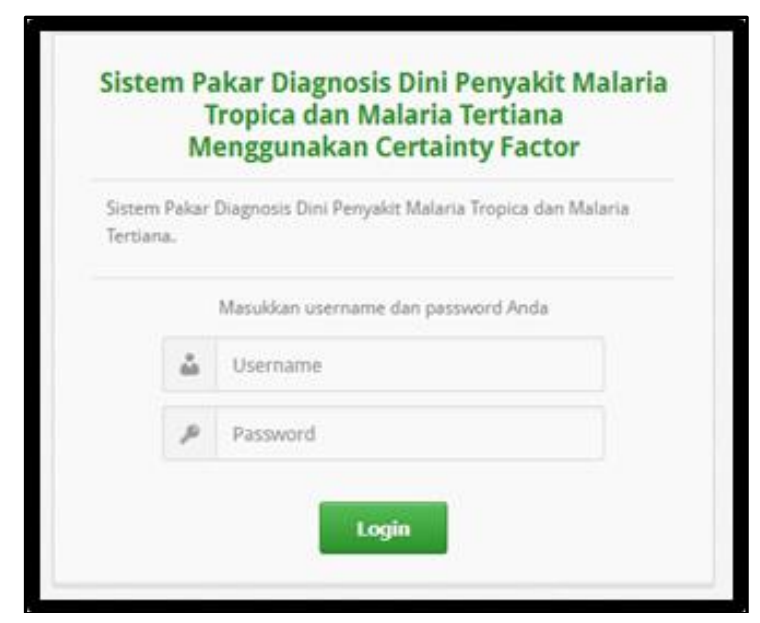

Figure 3. Login Form

After the admin has successfully logged in, the admin will enter the main menu which contains disease data, symptom data, knowledge base, and disease diagnosis results. The main menu form can be seen in Figure 4.

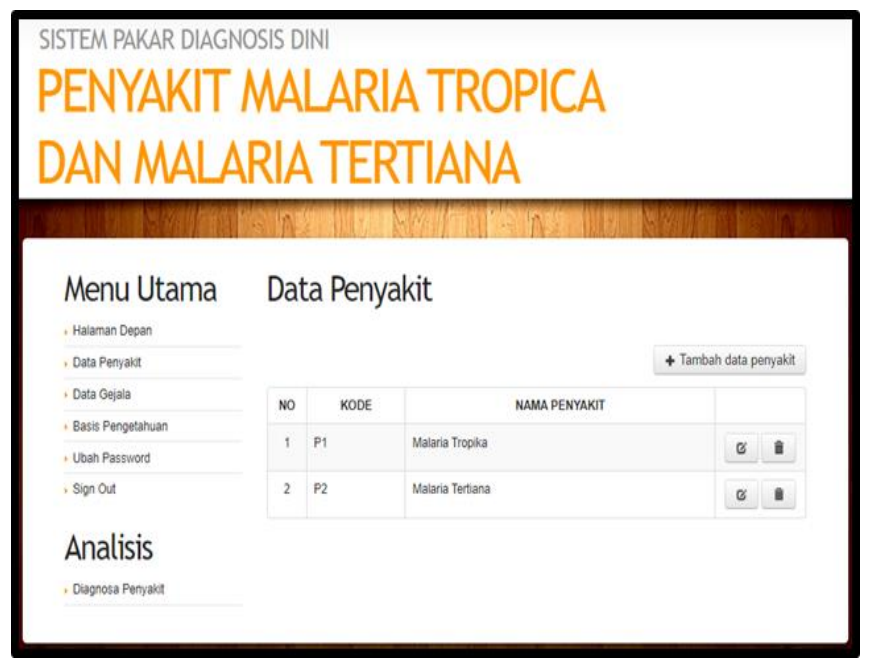

Gambar 4. Menu Utama

In symptom data, admins can add, edit, and delete symptom data given by doctors. Symptoms data can be seen in Figure 5. 
International Journal of Computer and Information System (IJCIS)

Peer Reviewed - International Journal

Vol : Vol. 02, Issue 04, November 2021

e-ISSN : 2745-9659

https://ijcis.net/index.php/ijcis/index

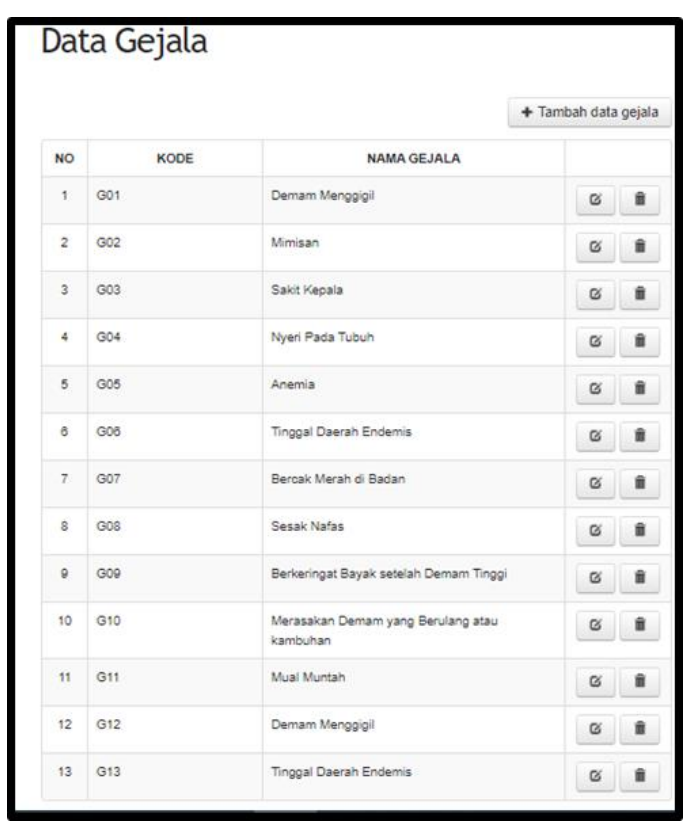

Figure 5. Symptom data

Next, the admin enters the knowledge base data for each symptom that has been obtained from the doctor. Knowledge base data can be seen in Figure 6.

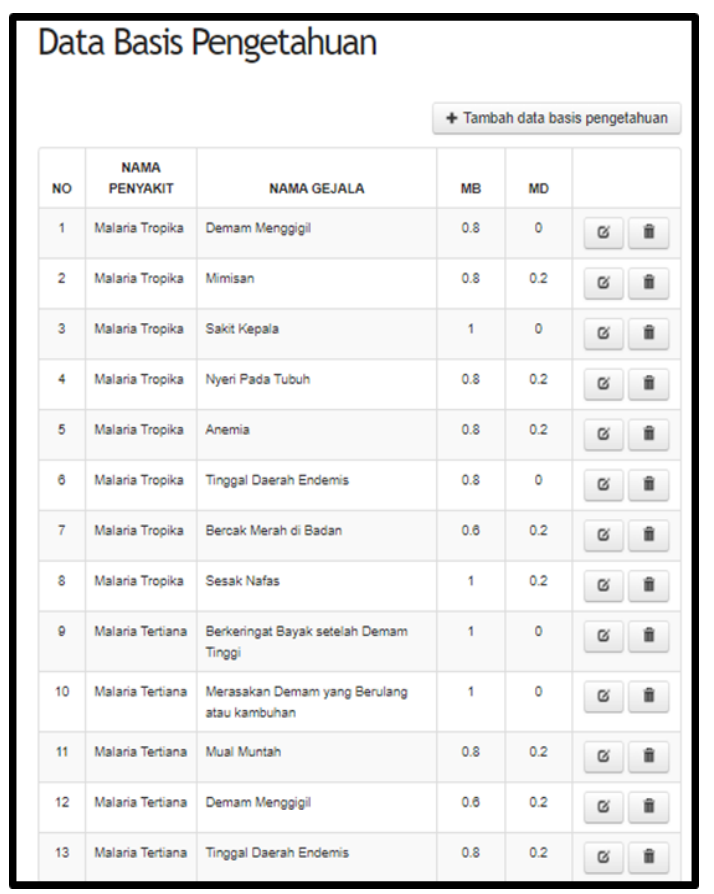

Figure 6. Knowledge Base Data

For the patient data page, you can directly diagnose the disease independently by selecting the symptoms you feel. Diagnosis of the disease can be seen in Figure 6.

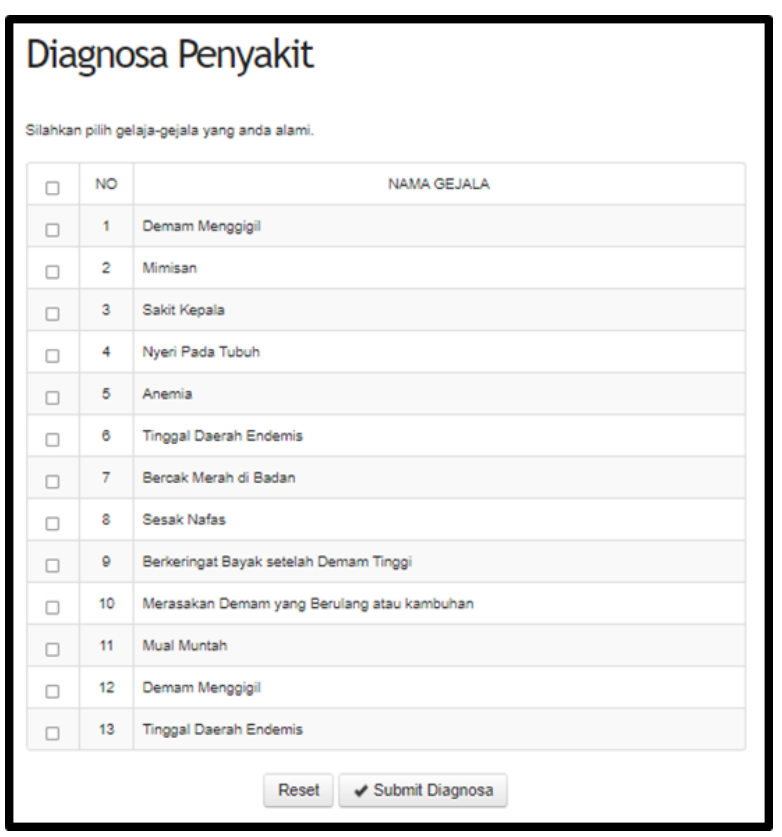

Figure 6. Disease diagnosis

After the patient selects the symptoms in the diagnosis of the disease, the patient chooses to submit a diagnosis to get the results of the diagnosis shown in Figure 7.

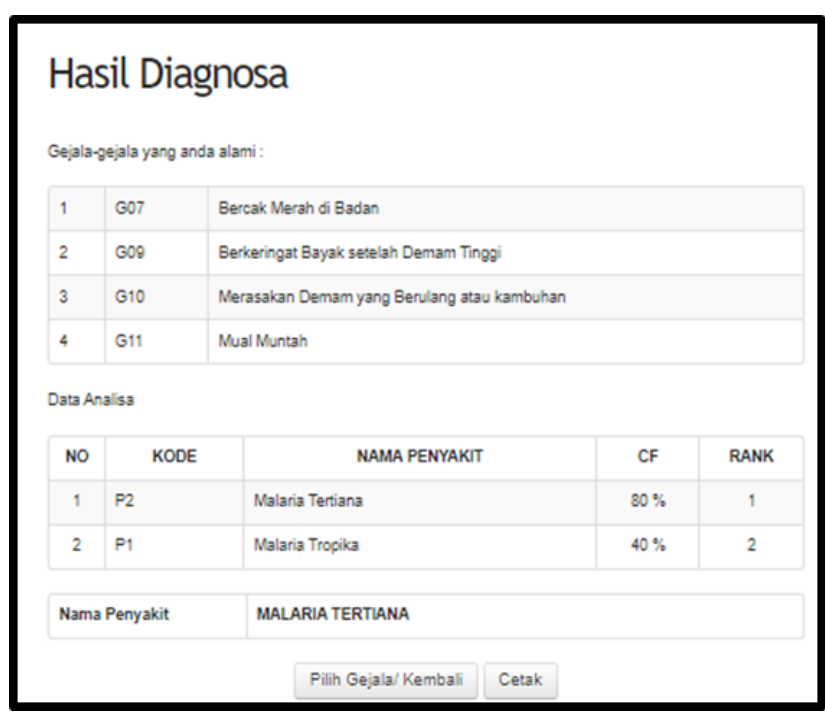

Figure 7. Diagnostic results

\subsection{System Testing}

In system testing, the aim is to find out the results of the expert system design that has been built by the objectives of the expert system for the early diagnosis of tropical and tertian malaria.

\section{Blackbox Testing}

This black box testing method is used in software testing. The focus of this method is more on the functional requirements of the expert system by detecting errors in the expert system. The results of the black box test can be seen in table 3 . 
International Journal of Computer and Information System (IJCIS)

Peer Reviewed - International Journal

Vol : Vol. 02, Issue 04, November 2021

e-ISSN : 2745-9659

https://ijcis.net/index.php/ijcis/index

Table 3. Blackbox testing

\begin{tabular}{c|l|l|c}
\hline No & $\begin{array}{c}\text { Testing } \\
\text { Scenario }\end{array}$ & Expected results & Status \\
\hline 1 & $\begin{array}{l}\text { Click the } \\
\text { admin login } \\
\text { button }\end{array}$ & $\begin{array}{l}\text { The system can } \\
\text { log in user and } \\
\text { password }\end{array}$ & Valid \\
\hline $\begin{array}{l}\text { Admin edits } \\
\text { disease data, } \\
\text { symptoms, } \\
\text { and } \\
\text { knowledge } \\
\text { base. }\end{array}$ & $\begin{array}{l}\text { The system } \\
\text { displays disease } \\
\text { datar symptoms, } \\
\text { and knowledge } \\
\text { base. }\end{array}$ & Valid \\
$\begin{array}{l}\text { The patient } \\
\text { chooses the } \\
\text { symptoms } \\
\text { of the } \\
\text { disease }\end{array}$ & $\begin{array}{l}\text { The system can } \\
\text { display a page of } \\
\text { symptoms and } \\
\text { diagnostic results }\end{array}$ & Valid \\
\hline
\end{tabular}

2. Patient Sample Recapitulation

The results of the recapitulation of 5 TWANO puskesmas patients who also tested the system by entering the symptoms experienced in table 4 .

Tabel 4. Patient Sample Recapitulation

\begin{tabular}{c|l|c|c}
\hline No & Diagnostic Results & $\begin{array}{c}\text { Number } \\
\text { of people }\end{array}$ & Percentage \\
\hline 1 & Tropical Malaria & 2 & $40 \%$ \\
2 & Tertiana Malaria & 2 & $40 \%$ \\
3 & Not Both Diseases & 1 & $20 \%$ \\
\hline
\end{tabular}

Based on the 5 patient samples used, there was 1 patient who was not detected with what kind of malaria, then further examination was needed.

\section{CONCLUSION}

After the Expert System for Early Diagnosis of Tropical and Tertian Malaria Using Certainty Factor, what can be drawn in this study is the knowledge from a doctor who is entered into the expert system can assist patients in early diagnosing what type of malaria the patient is experiencing. Supported by the results of the sample recapitulation test, namely 5 patients, $40 \%$ had the potential to experience tropical malaria, $40 \%$ had the potential to experience tertian malaria, and $20 \%$ had no detectable type of malaria. So the total accurate patient recapitulation results are $80 \%$ of the Expert System for Early Diagnosis of Tropical Malaria and Tertiana Using Certainty Factors. This method is suitable for use in expert systems that contain uncertainty

\section{REFERENCES}

[1] A. F. Zohra, S. Anwar, A. Fitri, and M. H. Nasution, "Klasifikasi Wilayah Provinsi Aceh Berdasarkan Tingkat Kerentanan Kasus Malaria Tahun 2015 - 2018," J. Kesehat. Lingkung. Indones., vol. 18, no. 1, p. 25, 2019, doi: 10.14710/jkli.18.1.25-33.

[2] S. A. Fitriany J, "Malaria," J. Averrous, vol. 4, no. 1, pp. 1031, 2018, [Online]. Available: https://dx.plos.org/10.1371/journal.pntd.0004195\%0Ahttp:// malariajournal.biomedcentral.com/articles/10.1186/s12936016-1588-

8\%0Ahttps://www.ajtmh.org/content/journals/10.4269/ajtmh. 2012.11-

0577\%0Ahttp://bmcmedicine.biomedcentral.com/articles/10. $1186 / \mathrm{s} 1291$.

[3] C. Anggraeny, "Imovasi Pelayanan Kesehatan," vol. 1, pp. 8593, 2013.

[4] J. Yos, S. No, A. K. Jawa, K. Lubuklinggau, and S. Selatan, "Implementasi sistem pakar untuk mendiagnosa penyakit dengan gejala demam menggunakan metode certainty factor," vol. 0 , no. 01, pp. 1-8, 2019.

[5] P. Hasan, E. W. Sholeha, Y. N. Tetik, and K. Kusrini, "Sistem Pakar Diagnosa Penyakit Kolesterol Dan Asam Urat Menggunakan Metode Certainty Factor," Sisfotenika, vol. 9, no. 1 , p. 47, 2019, doi: 10.30700/jst.v9i1.448.

[6] H. Pratama, I. F. Astuti, and D. Cahyadi, "Sistem Pakar Berbasis Web Diagnosa Penyakit THT (Telinga, Hidung, Tenggorokan) Menggunakan Metode Certainty Factor," Pros. Semin. Nas. Ilmu Komput. dan Teknol. Inf., vol. 2, no. 2, pp. $1-8,2017$.

[7] A. P. Kusuma, A. Sugiarto, P. Studi, T. Informatika, K. Blitar, and J. Timur, "Perancangan Dan Implementasi Sistem Pakar Diagnosis Pertolongan Pertama Penyakit Akibat Gigitan Nyamuk," vol. 12, no. 1, pp. 27-31, 2020.

[8] Y. Permana, I. G. P. S. Wijaya, and F. Bimantoro, "Sistem Pakar Diagnosa Penyakit Mata Menggunakan Metode Certainty Factor Berbasis Android," J. Comput. Sci. Informatics Eng., vol. 1, no. 1, p. 1, 2018, doi: 10.29303/jcosine.v1i1.11.

[9] F. Irhamn and D. Siahaan, "Object-Oriented Data Flow Diagram Similarity Measurement Using Greedy Algorithm," 2019 1st Int. Conf. Cybern. Intell. Syst. ICORIS 2019, vol. 1, no. August, pp. 274-278, 2019, doi: 10.1109/ICORIS.2019.8874895.

[10] Kusrini, K., Luthfi, E. T., Muqorobin, M., \& Abdullah, R. W. (2019, November). Comparison of Naive Bayes and K-NN Method on Tuition Fee Payment Overdue Prediction. In 2019 4th International Conference on Information Technology, Information Systems and Electrical Engineering (ICITISEE) (pp. 125-130). IEEE. 